\title{
A SYSTEMIC SUSTAINABILITY EVALUATION BASED ON WATER AND SANITARY CONDITIONS IN VELACHERY SETTLEMENT IN SOUTH INDIA
}

\author{
MONTO MANI ${ }^{1}$, K. VARGHESE ${ }^{2}$ \& L.S. GANESH ${ }^{3}$ \\ ${ }^{1}$ Centre for Sustainable Technologies, Indian Institute of Science, India. \\ ${ }^{2}$ Department of Civil Engineering, Indian Institute of Technology, Madras, India. \\ ${ }^{3}$ Department of Management Studies, Indian Institute of Technology, Madras, India.
}

\section{ABSTRACT}

An integrated study into the sustainability of human settlements requires a holistic consideration of the interlinked natural and human processes. This paper presents an integrated study on the sustainability of a human settlement, using community attitudes and the living environment as determinants of sustainability. This exercise is unique in the fact that it emphasizes a systemic evaluation of sustainability, avoiding the temptation of simulation models. Such exercises would improve the modelers' insight and ability to understand the likely implications of human actions and their impact on sustainability. Human settlements, particularly suburban residential areas in the developing world, face an unprecedented array of problems attributed to unhealthy living environments. This study is based on a suburban community of approximately 3,000 families, residing around a lake in Velachery, South India. The study involves three community surveys and adopts a systemic approach to evaluate sustainability by assessing likely impacts of the community's lifestyle on its living environment.

Keywords: attitude, health, human settlements, integrated study, lifestyle, sustainability, systems thinking, water and sanitation.

\section{INTRODUCTION}

Studies into human settlement conditions, their development trends and sustainability pose a challenging task [1] but are valuable for sustainable development. A systemic approach to sustainable development is crucial $[2,3]$. In its broadest sense, the sustainable component of the sustainable development paradigm implies that the current state of the living environment is healthy and can support healthy future generations. Besides the requirement to meet basic human needs, much of the sustainability debate centers on natural environment issues, and particularly the way the built environment impacts the natural environment.

A community's living environment comprises its built and natural environments. The last part of the 20th century has seen the emergence of an increasingly unsustainable living environment, reflected in terms of polluted air, water and soil, ill-health and disease, as well as a general decline and deterioration in biodiversity [4]. This is most evident in the case of residential areas in the developing world [5] and particularly pronounced in the suburbs.

In transforming nature into habitats, humans alter nature to varying degrees depending on their lifestyles. There exists a strong relation between the lifestyles pursued by a community and their sustainability. As lifestyles and activities of communities are governed to a large extent by their attitudes $[6,7]$ a strong connection can be established between community attitude and sustainability. This implies that present day community lifestyles (attitudes and activities) need to be evaluated for their impacts on sustainability.

A community (and its attitude) plays a crucial role in transforming living conditions into more healthy, liveable and environmentally conducive living environments [8-10]. Camagnia et al. [11] assert that alterations in personal lifestyles are one of the lesser known but very strong policy 
interventions to achieve sustainable development. The human dimension is crucial in determining sustainable development $[3,12]$. In studies dealing with sustainability of human settlements, the human-dimension 'attitude' has not been considered in a systemic manner.

Thus, the objective here is to conduct a systemic study into human-settlement sustainability, involving people's attitudes and their living environment. The intent is to also demonstrate the ability to evaluate sustainability at a very fundamental level, avoiding simulation models. Such an exercise would not only enhance our capacity to comprehend the causal relationships in the human-nature system $[13,14]$, but would also enable working under conditions of inadequate statistical data [15].

A suburban-residential settlement located in South India has been chosen as the study area. Sustainability evaluation has been on the basis of the community's water usage and sanitation practices. Water and sanitation are currently well recognized, globally, as vital issues threatening the sustainability of human settlements $[16,17]$.

\section{STUDY METHODOLOGY}

The integrated study methodology (Fig. 1) involves

- study area identification,

- study area data collection (preliminary and detailed community surveys), and

- compiling and analysis of data.

Select sets of experts conversant with the study area under consideration were consulted to ensure pertinent progress. These experts belong to various Central or State Government research institutions and were specialized in diverse disciplines, such as social sciences, urban hydrology, urban planning, and architecture. Consultations with these experts included one-to-one interactions (specific study-area observations) and integrated discussions (holistic study-area assessment) involving all the selected experts on three occasions.

\section{IDENTIFICATION AND DESCRIPTION OF THE STUDY AREA}

Velachery, a residential settlement situated in South Chennai (erstwhile Madras), India, has been chosen as the study area for this study (Fig. 2). Chennai, with a population of approximately 4.5 million and area of $174 \mathrm{~km}^{2}$, is the largest city in South India. Velachery surrounds a freshwater lake and comprises around 3,000 families. Compared to other residential areas, Velachery is relatively self-reliant in meeting its water and sanitation requirements. This is attributed to the fact that Velachery was originally a migrants' fringe settlement lacking basic services provided by the local municipality.

This settlement originated in the 1970s as an informal settlement of migratory laborers in search of employment in the city. With no access to municipal services, majority of the community had thus far been self-reliant in meeting its water and sanitation requirements and relied heavily on the lake's water. Its living environment to a large extent indicates a high level of self-initiated developments and transformations that are chiefly responsible in determining the state of its living conditions. Being among the deprived sections of the city, the community is politically very significant as an easily wooable high-density vote bank.

In recent years, Velachery has been incorporated within the city municipality service limits. Also, the Tamil Nadu Slum Clearance Board and the Tamil Nadu Housing Board procured large portions of the area surrounding the lake for relocating scattered city slums and selling plots of various sizes to families belonging to different income groups, namely economically weaker sections 


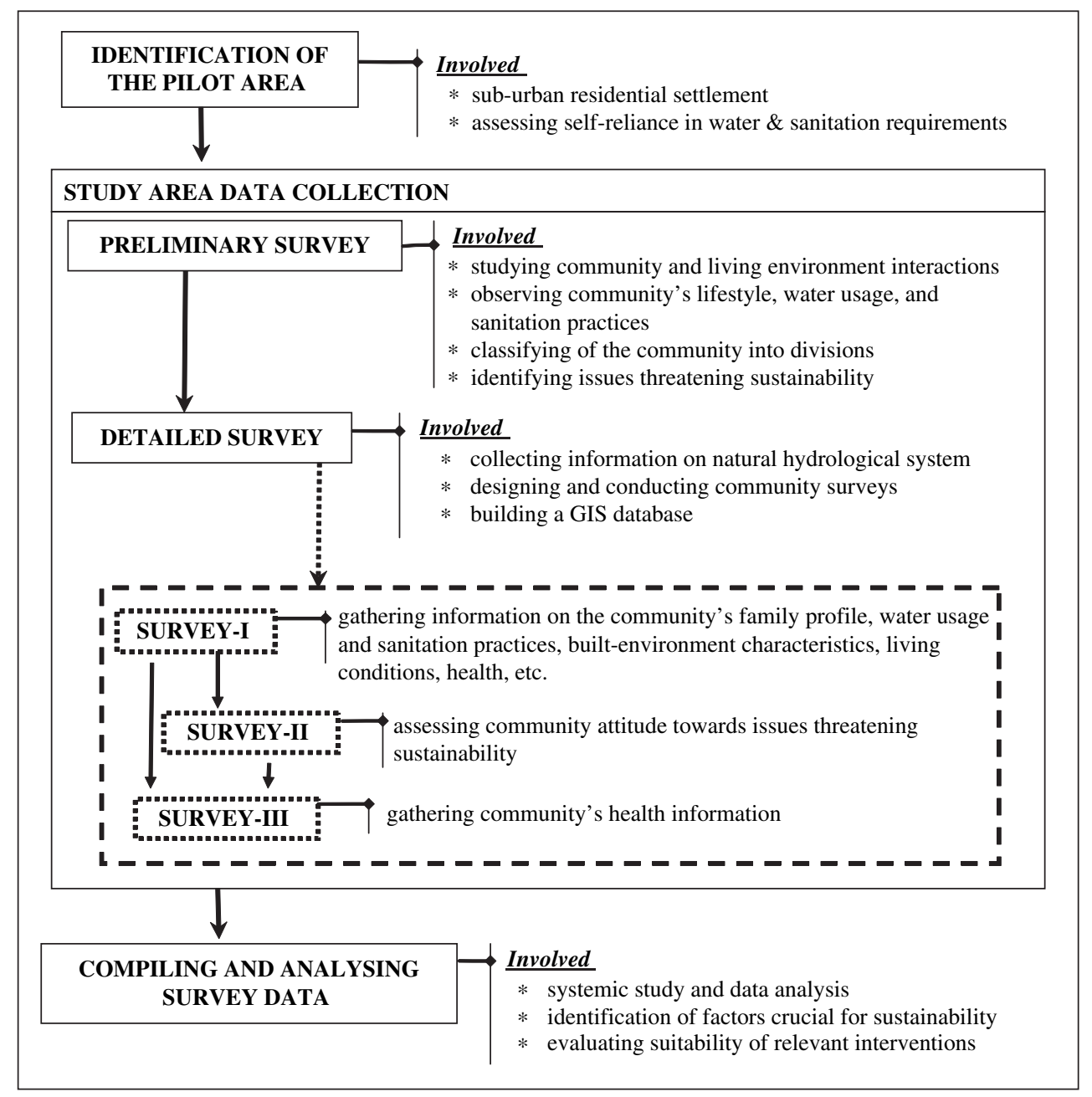

Figure 1: Study methodology.

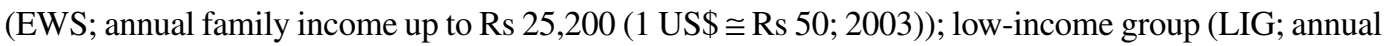

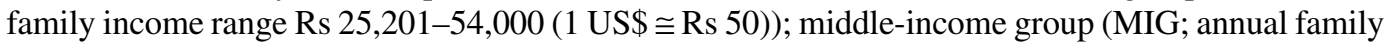

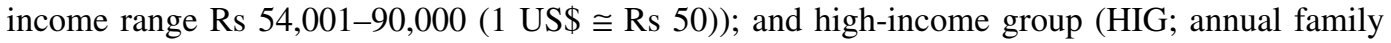
income above Rs 90,001 ( 1 US $\$ \cong$ Rs 50$)$ ). The study area exhibits wide diversity in terms of economic status, professions, lifestyles, and living conditions among different sections of the community (Tables 1 and 2). This diversity is exhibited as characterizable living environment features. Under the purview of the local municipality, limited water and sanitation infrastructure was provided and consequently the community's dependence on the lake receded. The lake that once drew large populations of settlers presently stands neglected and polluted. Limited services that have recently been provided by the municipal corporation, particularly with respect to water supply, include the installation of a Reverse Osmosis Water Treatment Plant (treating shallow well water) in the locality, drinking water supply (brought from distant lakes) by mobile tankers, and few sewer lines. 


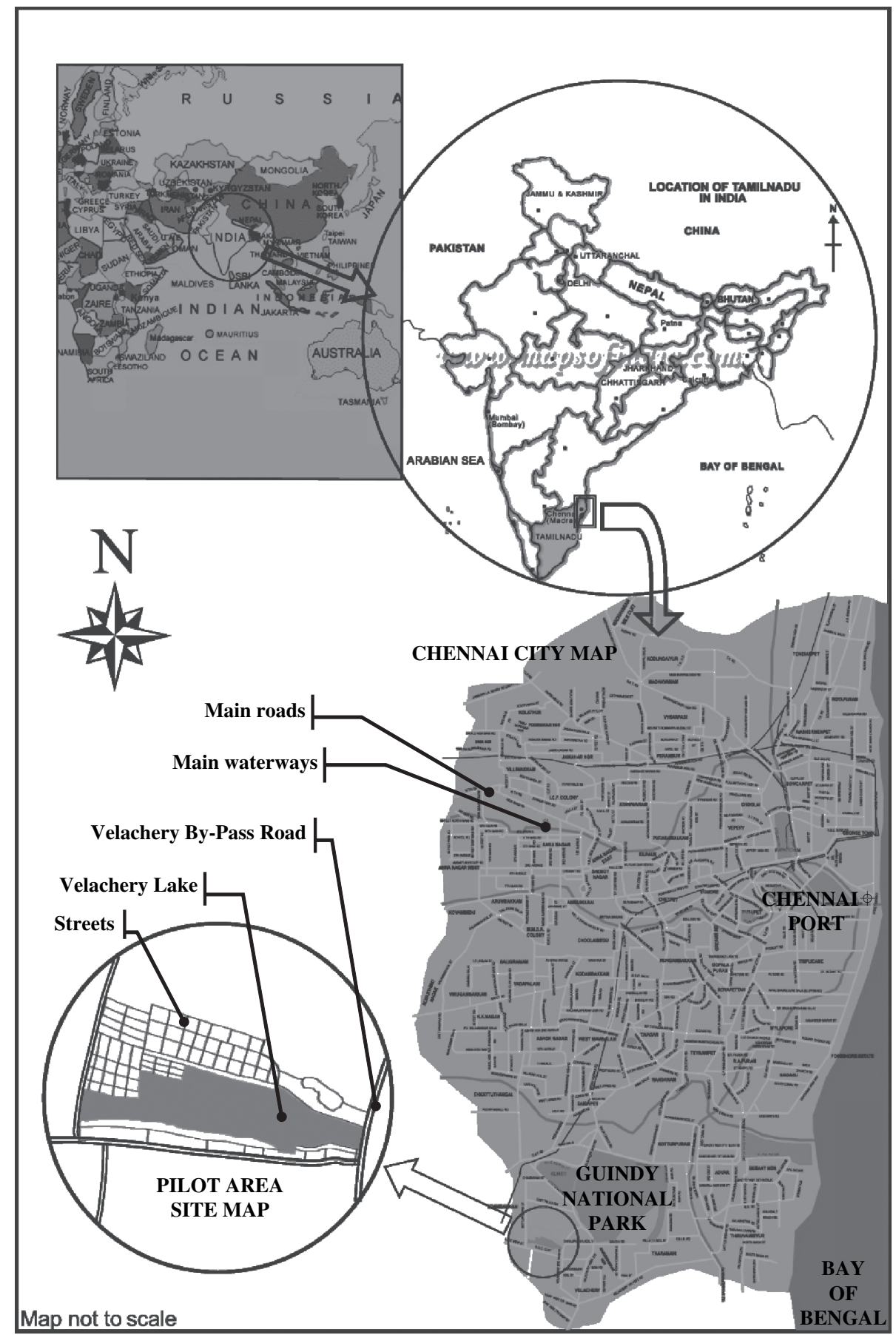

Figure 2: Study area location map. 
While the settlement originally relied heavily on the lake water, subsequent developments such as piped and trucked water supply have rendered the direct dependence on the lake unnecessary. In recent years, besides severe scarcity of clean drinking water, the community has been facing numerous problems in the form of a polluted lake and groundwater sources, unhealthy living conditions, inadequate hygiene, poor health and threats to social stability arising from inequitable water-access among different sections of the community.

\section{SYSTEMIC DELINEATION OF THE STUDY AREA}

Velachery covers an area of around 140 acres, with the lake occupying around 55 acres. The area receives an average annual rainfall of $1,330 \mathrm{~mm}$ from both the southwest (June-September) and northeast (October-December) monsoons. The natural slope of the study area is from the north to the south, with an embankment supporting the southern side of the lake (Fig. 3).

The lake's catchment area is approximately $10 \mathrm{~km}^{2}$. The lake has never run dry, even during the worst two-year drought that Chennai faced in 2001. The lake is actually an exposed water table (shallow aquifer), and has a strong impact on the state of the shallow wells in the locality. The depth of the water table is $4.57 \mathrm{~m}$. The deep aquifer is below a rocky stratum and extends from 19.8 to $45.73 \mathrm{~m}[18,19]$. This aquifer can be considered a confined aquifer theoretically, but in reality this would be untrue given the fact that extensive bore-well drillings have caused fissures that would permit some degree of water seepage.

\subsection{Study area data collection}

The study area data collection involved two stages - a preliminary survey and a detailed survey. Based on the preliminary surveys, the community was classified into 10 divisions, considering variations in the living environment characteristics and community lifestyles. A geographic information system (GIS) output illustrating the divisions' layout, including characteristics of the number of families and general income classes is presented in Fig. 4. Tables 1 and 2 present the salient features of each community division (Divisions I-X).

The community exhibits distinct variation in the sources of water for consumption and hygiene. These include shallow wells, deep wells, lake, reverse osmosis plant, metro water tankers, and bottled (purchased) water. The community's normal drinking water requirement is approximately 12.86 liters per capita per day (LCD). Hygiene water requirements vary from 39.8 LCD for communities belonging to the EWS, to 173 LCD for the communities belonging to LIGs and above. The sewage and sullage (gray water) from the community is disposed by various means, namely into open channels in the ground, through municipal sewer lines, into the lake, onto the roads, or into storm water drains that lead to the lake (Table 3). The community, the EWS in particular, faces numerous health problems attributed to improper water and sanitation practices. Diseases such as diarrhea, meningitis, malaria, cholera, intestinal helminthes, respiratory infections, dengue, infection of the respiratory tract, skin infections, and other non-communicable respiratory and digestive disorders are common.

Interaction with the local doctors (identified in the preliminary survey) revealed that unhygienic sanitation practices, inadequate precautions for water consumption, air pollution, and unhealthy living conditions are primarily responsible for the occurrence of these diseases.

The health parameters (expressed on a 0-1 scale) include the physical health levels, the life expectancy and the disease incidence levels expressed for both Generation-I (youth 18 years and above including the aged) and Generation-II (unborn children and the young below 18 years). This information was obtained by surveying doctors visited by the community. A subjective qualitative 


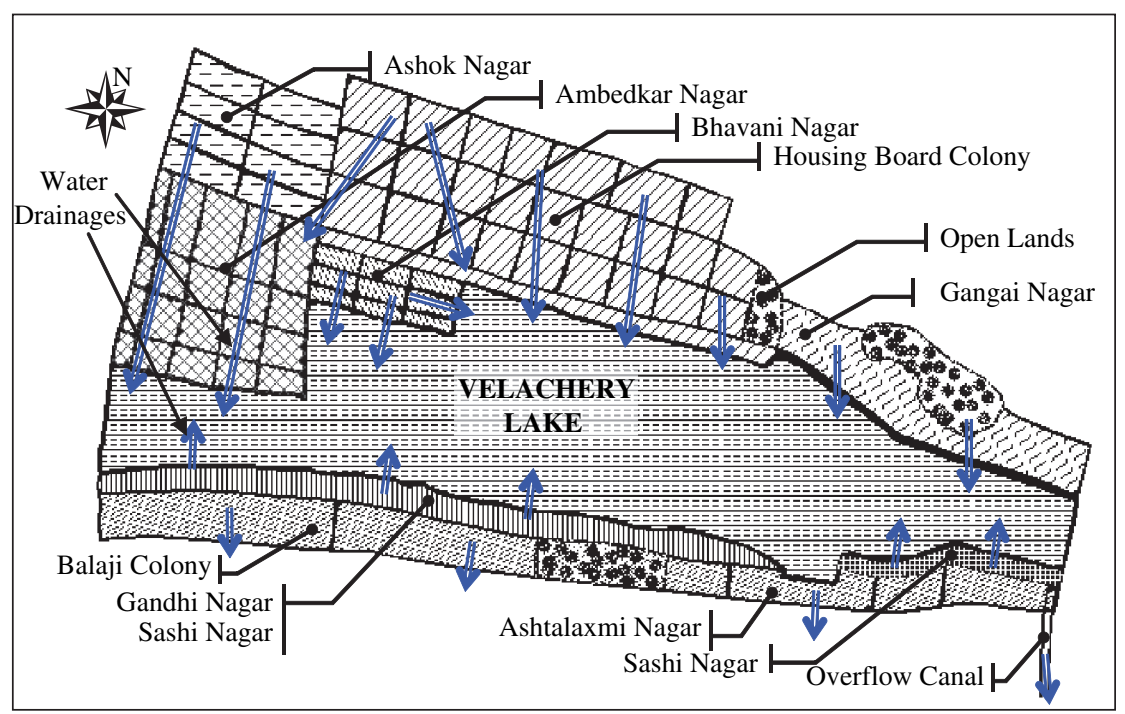

Figure 3: Velachery Lake (study area) surroundings (GIS output).

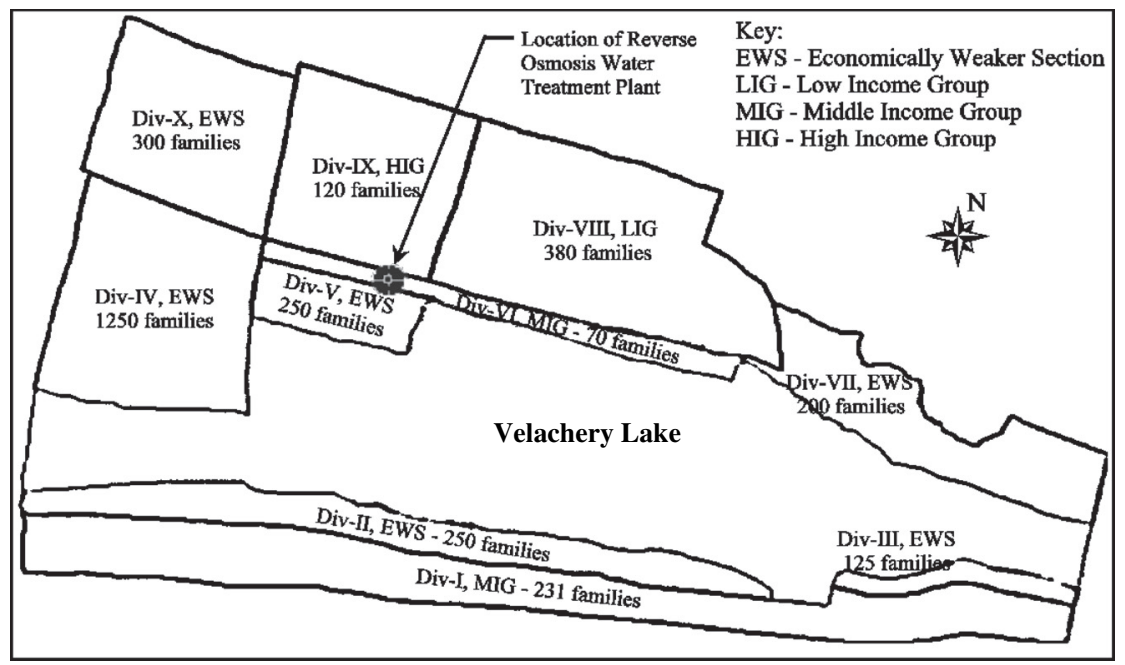

Figure 4: Study area - layout of divisions (GIS output).

scale was adopted for two reasons; first, statistical data pertaining to health was not available, and, second, it was easy to obtain a comparative idea of the varying health status among community divisions. When considering the above-mentioned health parameters, a higher value on the scale indicates better health, better life expectancy, and increasing disease incidences, respectively.

The health status at the time of this study for different community divisions is presented in Table 4. It can be seen that the health levels of the EWS, particularly the younger generations (Gen-II), are barely on the health threshold (rudimentary line dividing good and bad health). 
Table 1: Community's division-wise salient features.

\begin{tabular}{|c|c|c|c|c|}
\hline \multirow[b]{2}{*}{ Div. no. } & \multicolumn{2}{|c|}{ Family } & \multirow[b]{2}{*}{ Community characteristics } & \multirow{2}{*}{$\begin{array}{l}\text { Notable living environment } \\
\text { characteristics }\end{array}$} \\
\hline & No. & Size & & \\
\hline I & 230 & 4.82 & $\begin{array}{l}\text { MIG - predominantly } \\
\text { pensioners, and regular } \\
\text { employees from private- or } \\
\text { public-sector companies }\end{array}$ & $\begin{array}{l}\text { Not actively associated with the lake } \\
\text { Adversely affected due to close } \\
\text { proximity of the polluted lake and } \\
\text { its impact on the groundwater }\end{array}$ \\
\hline II & 250 & 5.17 & $\begin{array}{l}\text { EWS - predominantly } \\
\text { temporary laborers with } \\
\text { irregular incomes, } \\
\text { migratory settlers }\end{array}$ & $\begin{array}{l}\text { Shanty toilet and bathing facilities, } \\
\text { many defecate on the lake's edge } \\
\text { Discharge untreated sewage and } \\
\text { sullage directly into the lake } \\
\text { Community settled along lake's edge } \\
\text { due to easy water availability }\end{array}$ \\
\hline III & 125 & 4.57 & $\begin{array}{l}\text { EWS - predominantly } \\
\text { temporary laborers with } \\
\text { irregular incomes, } \\
\text { migratory settlers }\end{array}$ & $\begin{array}{l}\text { Discharge untreated sewage and } \\
\text { sullage directly into the lake } \\
\text { Community settled along lake's edge } \\
\text { due to easy water availability }\end{array}$ \\
\hline IV & 1,250 & 4.75 & $\begin{array}{l}\text { EWS - relocated } \\
\text { communities from city } \\
\text { slums provided with } \\
\text { modest dwelling units }\end{array}$ & $\begin{array}{l}\text { Public toilets and community wells } \\
\text { for washing and bathing } \\
\text { Div-IV Sullage water let into } \\
\text { clogged storm-water drains leading } \\
\text { to the lake or collected in nearby }\end{array}$ \\
\hline $\mathrm{V}$ & 250 & 4.45 & $\begin{array}{l}\text { EWS - relocated } \\
\text { communities from city } \\
\text { slums provided with site } \\
\text { and services only }\end{array}$ & $\begin{array}{l}\text { percolation pits and later strewn } \\
\text { onto the roads; Div-V Shanty } \\
\text { bathing facilities built right over } \\
\text { clogged storm-water drains } \\
\text { Very poor and unhygienic living } \\
\text { conditions - scattered waste and } \\
\text { mosquito infested stagnant pools }\end{array}$ \\
\hline VI & 70 & 3.6 & $\begin{array}{l}\text { MIG - regular employees } \\
\text { from private or public } \\
\text { sector, and businessmen }\end{array}$ & $\begin{array}{l}\text { Sewage and sullage pipes connected } \\
\text { to municipal sewer lines } \\
\text { Land allotted by the Tamil Nadu } \\
\text { Housing Board }\end{array}$ \\
\hline VII & 200 & 5.3 & $\begin{array}{l}\text { EWS - predominantly } \\
\text { temporary laborers with } \\
\text { irregular incomes, } \\
\text { migratory settlers }\end{array}$ & $\begin{array}{l}\text { Shanty toilet and bathing facilities, } \\
\text { many defecate on the lake's edge } \\
\text { Discharge untreated sewage and } \\
\text { sullage directly onto the main } \\
\text { road or into open canals leading } \\
\text { to the lake }\end{array}$ \\
\hline
\end{tabular}


Table 1: Continued.

\begin{tabular}{|c|c|c|c|c|}
\hline \multirow[b]{2}{*}{ Div. no. } & \multicolumn{2}{|c|}{ Family } & \multirow[b]{2}{*}{ Community characteristics } & \multirow{2}{*}{$\begin{array}{l}\text { Notable living environment } \\
\text { characteristics }\end{array}$} \\
\hline & No. & Size & & \\
\hline VIII & 380 & 4.3 & $\begin{array}{l}\text { LIG - regular employees } \\
\text { from private or public } \\
\text { sector }\end{array}$ & $\begin{array}{l}\text { Sewage and sullage pipes connected } \\
\text { to municipal sewer lines }\end{array}$ \\
\hline IX & 120 & 5.2 & $\begin{array}{l}\text { HIG - regular employees from } \\
\text { private or public sector, and } \\
\text { affluent businessmen }\end{array}$ & $\begin{array}{l}\text { Land allotted by the Tamil Nadu } \\
\text { Housing Board }\end{array}$ \\
\hline$X$ & 300 & 4.3 & $\begin{array}{l}\text { EWS, LIG - regular } \\
\text { employees and temporary } \\
\text { laborers }\end{array}$ & $\begin{array}{l}\text { Public toilets and community wells } \\
\text { for washing and bathing } \\
\text { Sullage water let into clogged } \\
\text { storm-water drains leading to the lake } \\
\text { Unhygienic living conditions - } \\
\text { scattered waste and } \\
\text { mosquito-infested stagnant pools }\end{array}$ \\
\hline
\end{tabular}

\subsubsection{Preliminary survey}

The purpose here was to gain a preliminary understanding of the community and its living environment, and to guide subsequent course of study. The survey involved:

- Observing the community's life style, particularly water usage and sanitation practices; informal interactions with community members.

- Studying interactions between the community and the natural environment to identify issues threatening the sustainability and well-being of the community. This focused on inadequate water and sanitation attributed to the community's lifestyle and its implications within the living environment. Information pertaining to community health and prevalent diseases were obtained based on interactions with the community and the doctors (visited by the community). Important observations and judgments were recorded on video tapes for subsequent discussions and experts' opinion/appraisal.

- Classifying the community into divisions (based on the diversity exhibited in the built environment), to take into consideration the diversity in the community for sustainability evaluation. Variations in the community's income levels are revealed through the builtenvironment characteristics [20] such as design and modes of construction, water supply, and sanitation.

\subsubsection{Detailed survey}

This exercise adopted a systemic approach to obtain detailed information on the community and its living environment. It involved:

- Building a GIS database for the study area, to store and represent spatial information associated with each community division. The base map was prepared from a $5.8 \mathrm{~m}$ resolution panchromatic satellite image. 


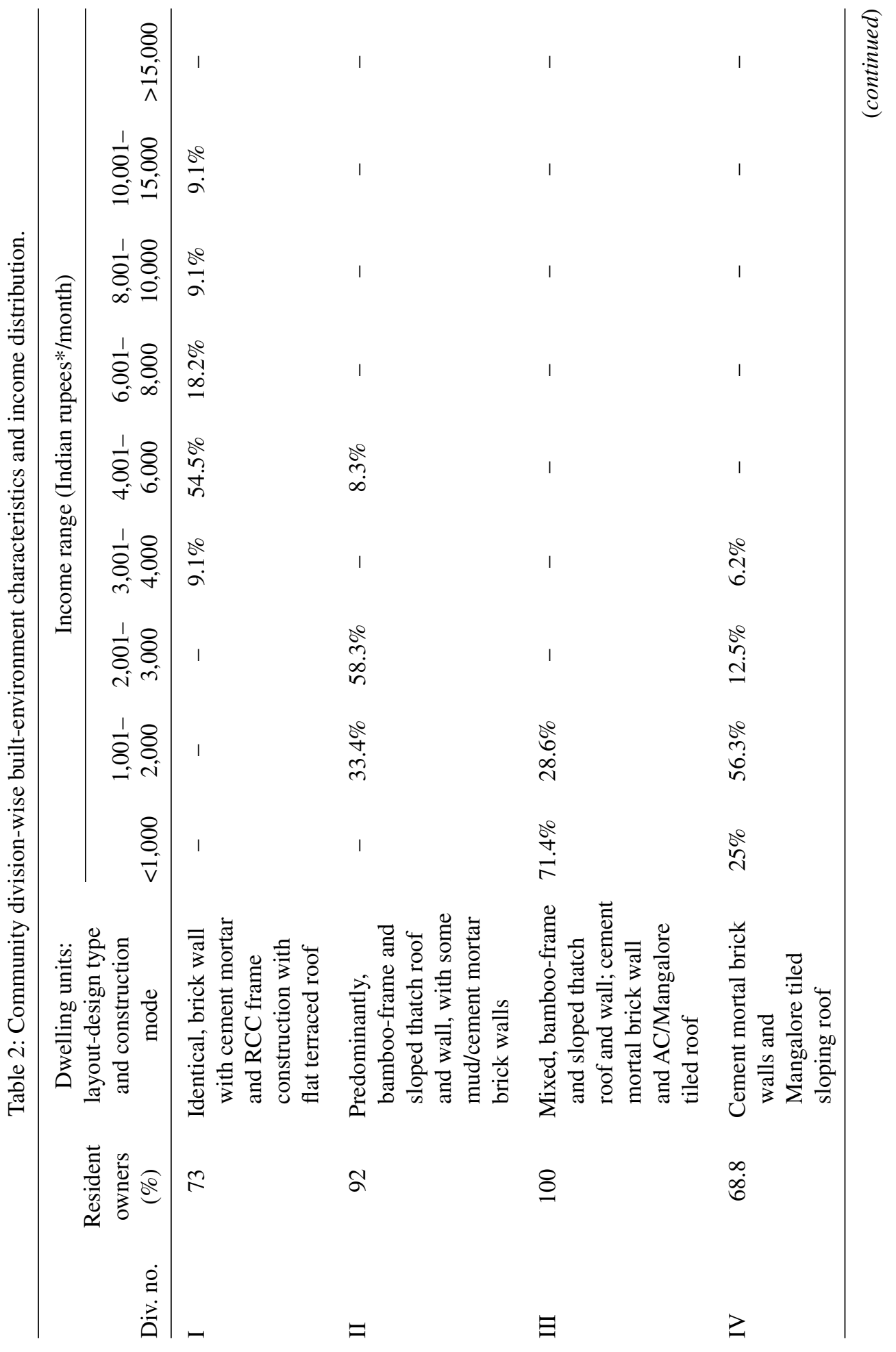


Monto Mani et al., Int. J. Sus. Dev. Plann. Vol. 2, No. 4 (2007)

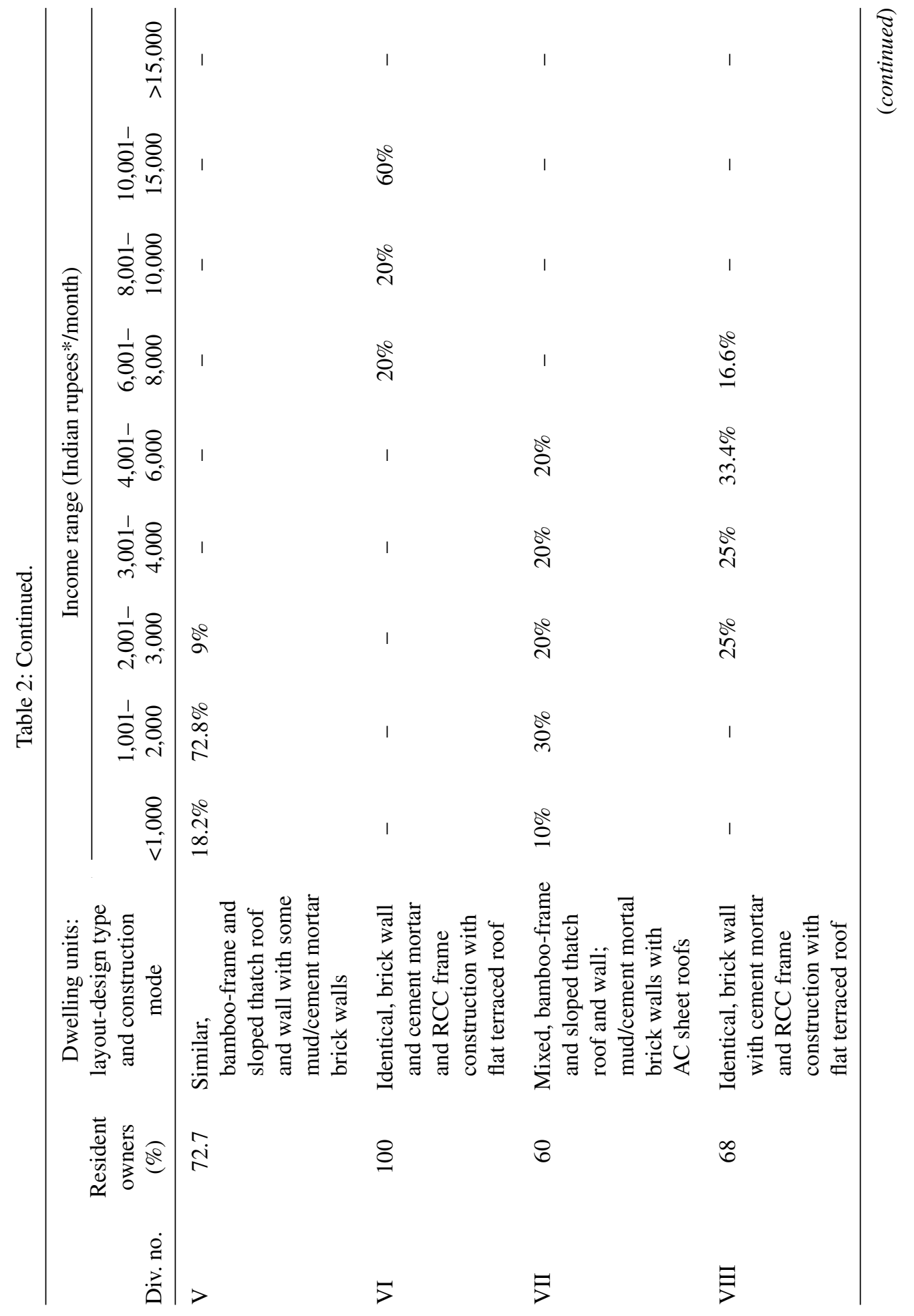




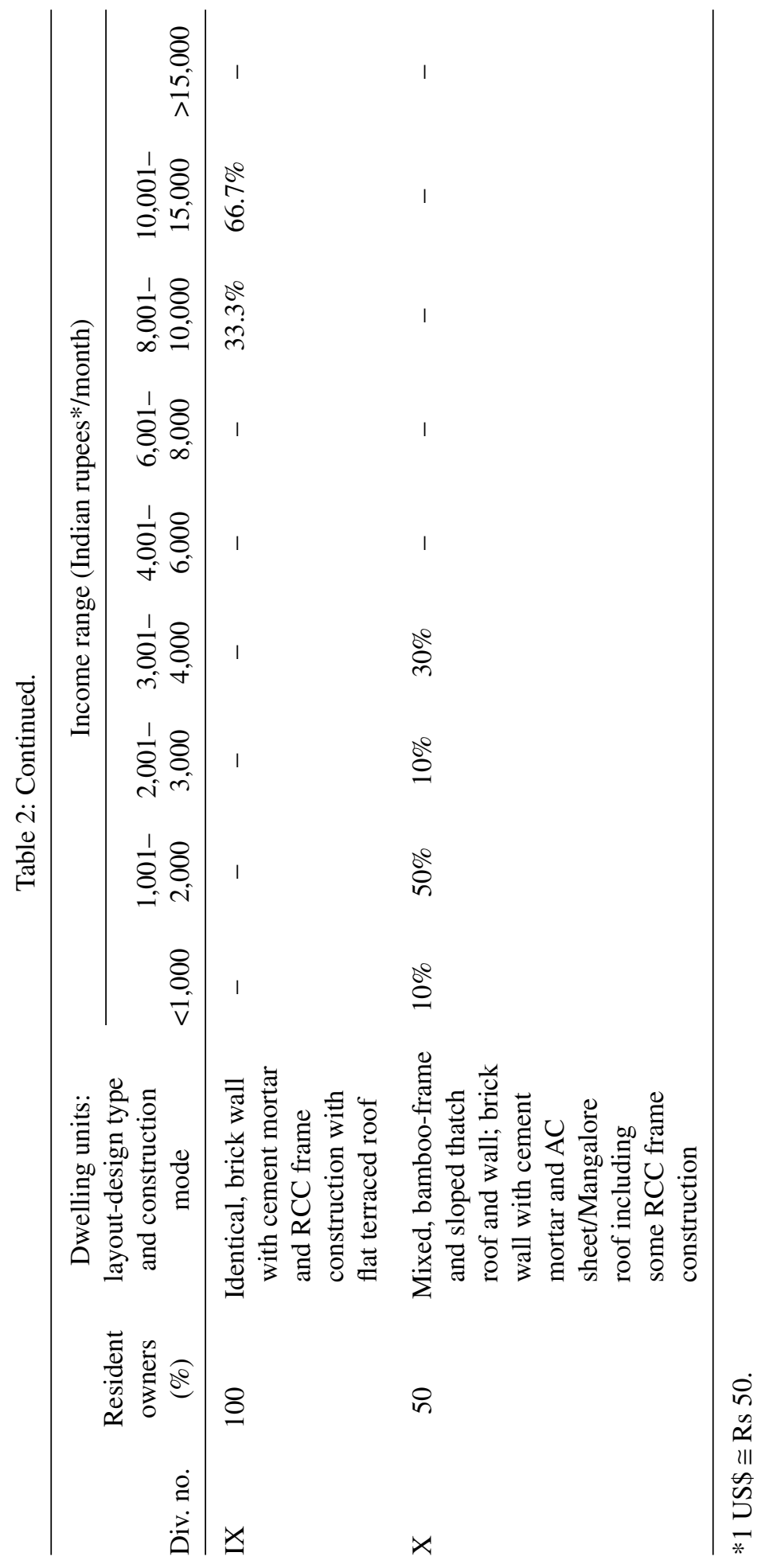


Monto Mani et al., Int. J. Sus. Dev. Plann. Vol. 2, No. 4 (2007)

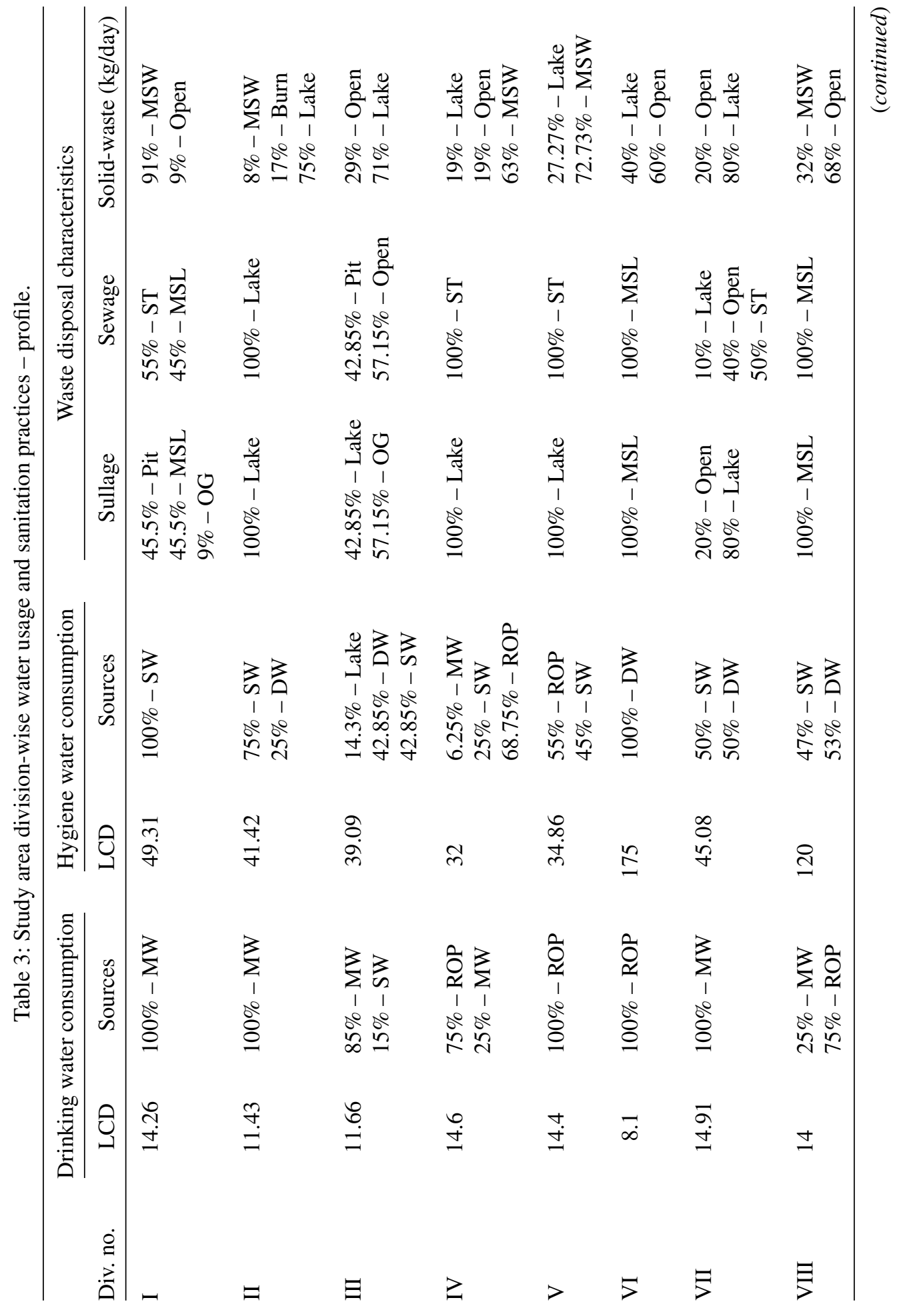




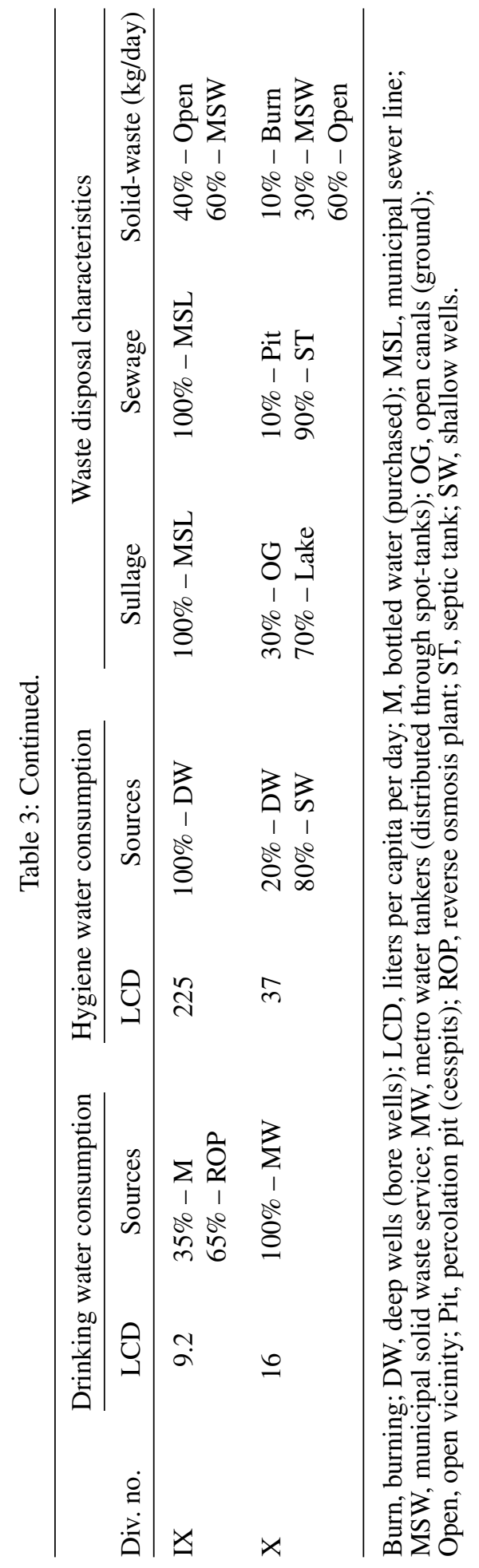




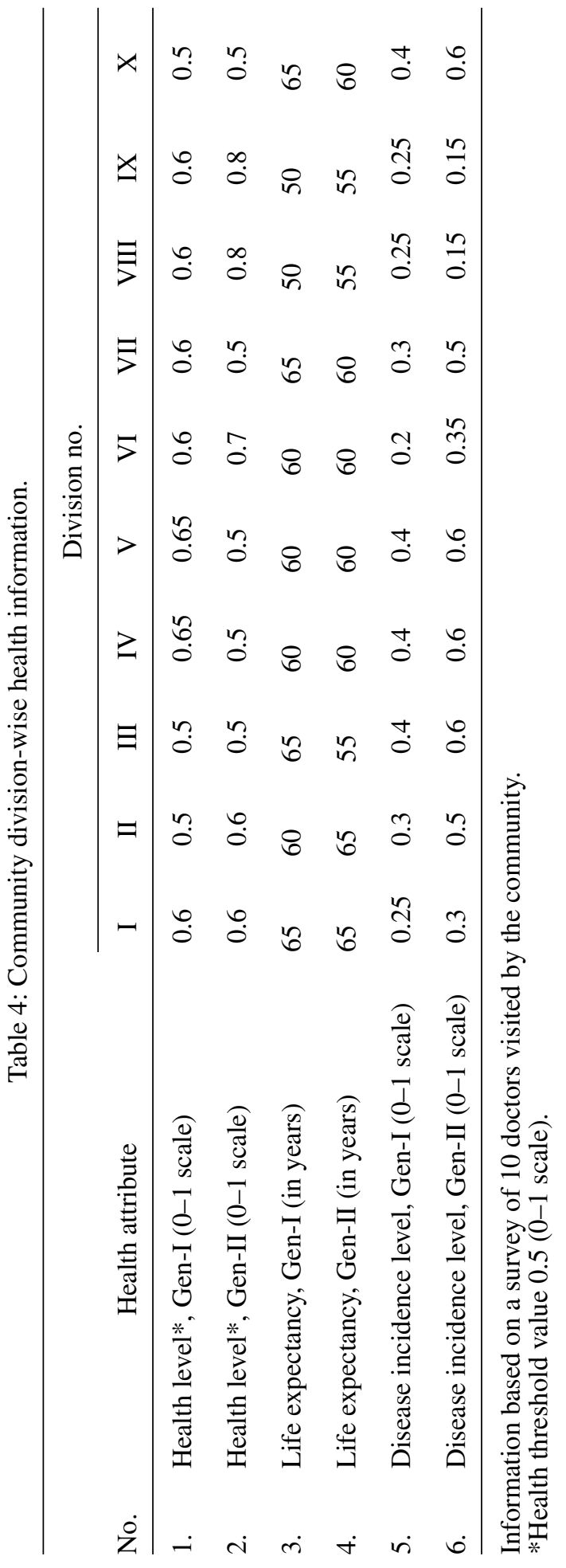


- Obtaining details on the underlying hydrological system, from published government reports and through discussions with relevant experts.

- Conducting water quality tests from samples of various water sources in the study area, namely the shallow wells, the bore wells, the reverse osmosis treatment plant, water supply tankers and the lake. The standards prescribed by the WHO were adopted in the collection and testing of water samples. Based on these tests, water-quality parameters not complying with standards for domestic consumption were identified, in addition to ascertaining implications of different water-quality parameters on community health [21-23].

- Designing and conducting community surveys to obtain detailed information on the community's living environment, lifestyles, attitudes, health, and well-being. Three sets of surveys were found necessary. In designing the surveys, many national and foreign community survey designs were referred, and experts from the Department of Humanities and Social Sciences of the Indian Institute of Technology Madras were also consulted. Pilot surveys were initially conducted to verify the suitability of the survey design. Necessary modifications were incorporated.

The survey sample size for the community divisions varied from $2 \%$ to $5 \%$, depending on the uniformity in the survey responses. This range complies with the minimum sample size adopted for similar surveys conducted by the National Sample Survey Organization, India [24]. A stratified random sample survey was adopted. The classification of the community into divisions, based on livingenvironment characteristics, forms the basis for the stratification. The survey was addressed to families that were resident (owners or tenants) in Velachery for more than 5 years. This was to ensure that the survey-sample respondents had a good degree of awareness of their living environment.

The first survey (Survey-I) was designed to obtain information on the community's water usage and sanitation practices, built-environment characteristics and the state of the living conditions, and health profiles, namely

- community family profile - size, age distribution, income;

- water consumption practice - source, quantity consumed, and purpose;

- trends in the natural water sources - pollution levels (on a subjective scale), availability;

- $\quad$ sanitation practices - mode of sanitation, disposal practice;

- waste disposal practice - solid waste characteristics, mode of disposal;

- health profile - incidence of diseases, cause of disease, doctors visited;

- built-environment characteristics - open area characteristics, construction mode.

Community responses pertaining to various issues threatening different divisions of the community were obtained. Through the pertinent design and application of such surveys, it is crucial to identify community practices responsible for the deteriorating living conditions [25-27]. Each survey took approximately $15-20 \mathrm{~min}$, and primarily addressed the housewives as they were chiefly responsible for managing the household.

The second survey (Survey-II) assessed the community's attitude toward addressing issues threatening its sustainability, which were identified in Survey-I. This survey also served to obtain data on the community's likely responses in times of water scarcity, alternative water sources and their accessibility, and tendencies to adopt appropriate alleviation measures.

Attitude assessment involves an assessment based on its components toward an attitude object (e.g. rain water harvesting $(\mathrm{RWH})$ ), namely cognition (what a person knows about the object), feeling (what a person feels toward the object), and an action component (what is a persons' action tendency 
toward the object) $[6,28]$. The Likert scale technique is an available technique for such assessments. Assessments are usually on a positive/negative $0-1$ (or 0-5) scale corresponding to the degree of agreement or disagreement expressed by the subject; a ' -1 ' (or ' -5 ') would correspond to total disagreement, whereas a ' +1 ' (or ' +5 ') to total agreement.

Community's attitudes were assessed in response to the following issues (attitude objects):

- healthy living conditions and well-being,

- awareness of and concern for the natural hydrological processes,

- polluted lake and groundwater,

- situations of extreme water scarcity, and

- healthy water usage and sanitation practices.

Survey results were compiled and analyzed for every community division to evaluate sustainability. This was done for each division under consideration as well as the community as a whole.

Survey-II involved identifying, based on community responses, select alternatives to alleviate issues threatening sustainability. It also involves measuring community's attitude tendencies (willingness) to adopt different viable alternatives. This survey involves the entire household to obtain a collective response from every family.

The third survey (Survey-III) was conducted to obtain information on the health problems faced by the community, and to identify underlying issues. The community, in general, was found to be reluctant in disclosing health problems. To obtain reliable information on the community's health, the doctors visited by the community (identified from Survey-I) were surveyed. Information on the interrelationships between different health variables were also obtained to enable an understanding of the systemic linkages that determined community health. The doctors were selected such that their clinic/hospital was within the study area, and were visited by residents from at least two community divisions.

To study the sustainability of the community, the community was considered as two generations, namely the current/active generation - Generation-I, and the generation to follow - Generation-II. Information on the community's health was obtained, subjectively, on a $0-1$ scale. For example, a value of ' 0.1 ' would represent extremely poor health (including illness-induced physical disability), while ' 0.9 ' would correspond to a very healthy individual. This permitted a common base for qualitative comparison and expression of various health parameters across community divisions.

\subsection{Compiling and analyzing survey data}

This step represents the most crucial exercise of this study. Available computational facilities were utilized to handle the large amount of survey data and collate them into tabulated information. Systems thinking and data analysis concepts were adopted. The purpose of this exercise was to establish systemic linkages between the living environment and the community, and ascertaining cause-effect relationships underlying these linkages. A systemic approach to sustainability entails considering various entities or components interacting in the world as systems. The world itself can be thought of as a very large complex system containing complex subsystems such as ecological and biological systems, weather systems, and human social and economic systems.

A systemic structure diagram was generated, illustrating the linkages between components of the community, its living environment, water usage and sanitation practices, and health. Through this exercise it is possible to evaluate the sustainability of the settlement, and identify various factors, 
attributed to the community, that strongly influence this sustainability. This is a very fundamental exercise vital to understanding systems behavior and would normally precede the development of complex simulation models.

\section{SUSTAINABILITY EVALUATION OF THE STUDY AREA}

A structure diagram illustrating the interactions between different components of the living environment and the community is presented in Fig. 5. This diagram enables a better understanding of the systemic linkages that govern sustainability, besides guiding rational analysis and the identification of viable alternatives.

The factors identified for sustainability evaluation represent different aspects of the community, namely its physical health, well-being, and lifestyle. The physical health and well-being is representative of the health status of the community members and includes health level, life expectancy, and disease incidence levels. Lifestyle is representative of the community's current practices within the living environment, and includes the community's time and/or money spent toward procuring water, and tendency to migrate under conditions of severe water scarcity. Sustainability of various community divisions has been evaluated.

Reducing external factors (determinants) such as state administration and their influences was important to limit the scope of the study. These considerations would enable

- a focused study into the community's impact on its own sustainability,

- identifying issues threatening community sustainability and the factors responsible,

- verifying the role of the community's attitude on its sustainability, and

- formulating a basis for identifying suitable interventions for sustainable development.

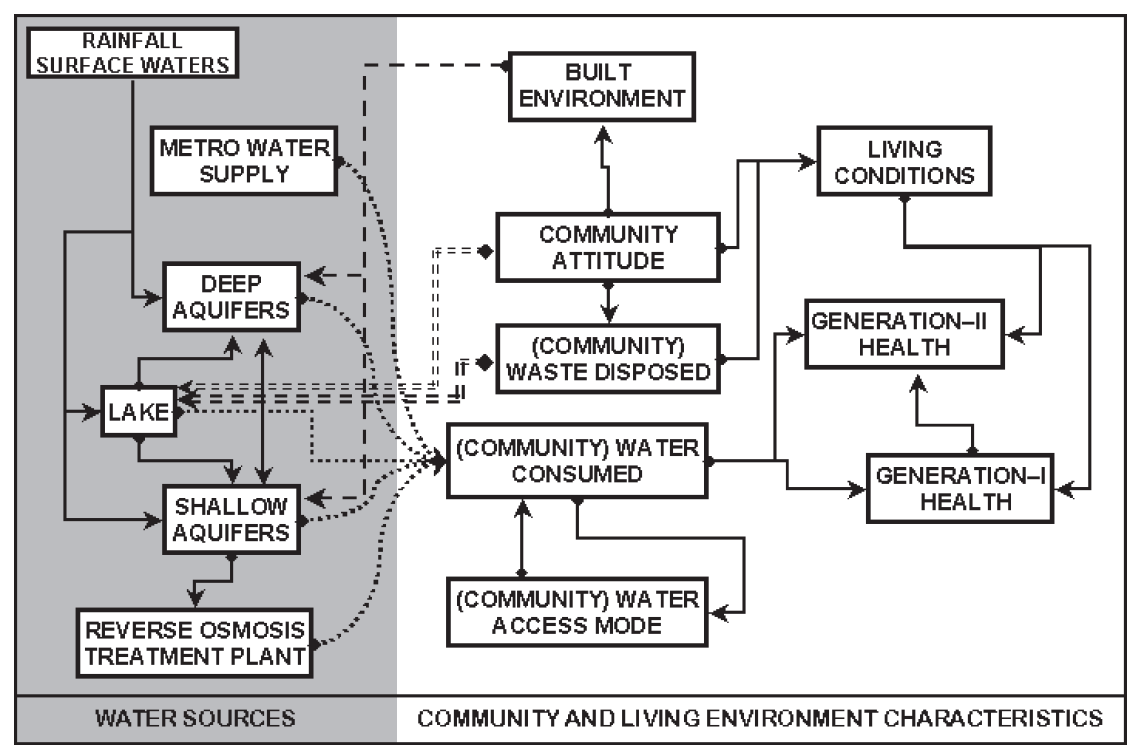

Figure 5: Component structure diagram. 
Table 5: Water-quality test results for salient parameters - different sources.

\begin{tabular}{llccccccc}
\hline No. & Parameter & SW & DW & Lake & MW & RO & WHO $^{\#}$ & $\begin{array}{c}\text { IS 10500 } \\
(1991)^{\#}\end{array}$ \\
\hline 1. & $\begin{array}{l}\text { Total dissolved } \\
\text { solids (mg/L) }\end{array}$ & 976 & 1,810 & 1,050 & 350 & 1,426 & 1,000 & 2,000 \\
2. & $\begin{array}{l}\text { Sulfate as } \mathrm{SO}_{4} \\
(\mathrm{mg} / \mathrm{L})\end{array}$ & 255.87 & 451.97 & 255.87 & 135.6 & 99.95 & 200 & 200 \\
$3 . \quad \begin{array}{l}\text { Nitrate as } \mathrm{NO}_{3} \\
(\mathrm{mg} / \mathrm{L})\end{array}$ & 10.625 & 3.75 & 19.375 & 6.5 & 10 & 10 & 45 \\
$4 . \quad \begin{array}{l}\text { Coliform } \\
\text { bacteria } \\
(\mathrm{MPN} / 100 \mathrm{~mL})\end{array}$ & $>500$ & Nil & $>2,000$ & $>50$ & $>100$ & Nil & Nil \\
\hline
\end{tabular}

DW, deep well; MW, metro water tanker supply; RO, reverse osmosis water treatment plant; SW, shallow well.

\#Maximum permissible limits as per Bureau of Indian Standards 10500 (1991) and WHO.

Tables 1-4 comprise information compiled from the surveys. Water-quality test results (for salient water-quality parameters) for different sources of water are presented in Table 5. The tests indicate that for most of the water sources, the sulfate, nitrate, and bacterial contents are above WHO permissible limits. High sulfate contents are known to cause diarrhea, and other intestinal disorders. High nitrate content is likely to have an adverse impact on children, particularly unborn babies. High bacterial content in all the water sources (barring deep well water) is responsible for the occurrence of many diseases in the community.

Table 6 presents a summary of the community's (division-wise) attitude responses toward the availability of various water sources, alternative water sources, and their readiness to migrate under conditions of severe water scarcity and pollution. Migration (of part or whole of the community) would be indicative of the community's inability to sustain itself at the original location. The community's readiness to install RWH systems, to alleviate the problems of desiccating water table has also been assessed and presented in this table. From this table, it is possible to anticipate the likely sustainability trends for different community divisions. A summary of this sustainability assessment is presented in Table 7 .

Table 8 presents a compilation of the community's (division-wise) attitude responses toward a clean lake environment and hygienic living conditions. The adoption of well-known and traditional precautions, such as boiling water, by the community (division-wise) to avoid disease incidences, in the light of deteriorating water quality, is also presented in this table. Based on the information presented in Table 8, it is possible to anticipate the likely trends in health, well-being, and sustainability within the community. A summary of this sustainability assessment is presented in Table 9 .

\section{CONCLUSIONS}

This section presents salient conclusions drawn from the integrated study into the sustainability of a suburban residential settlement based on its attitude and living environment conditions. 


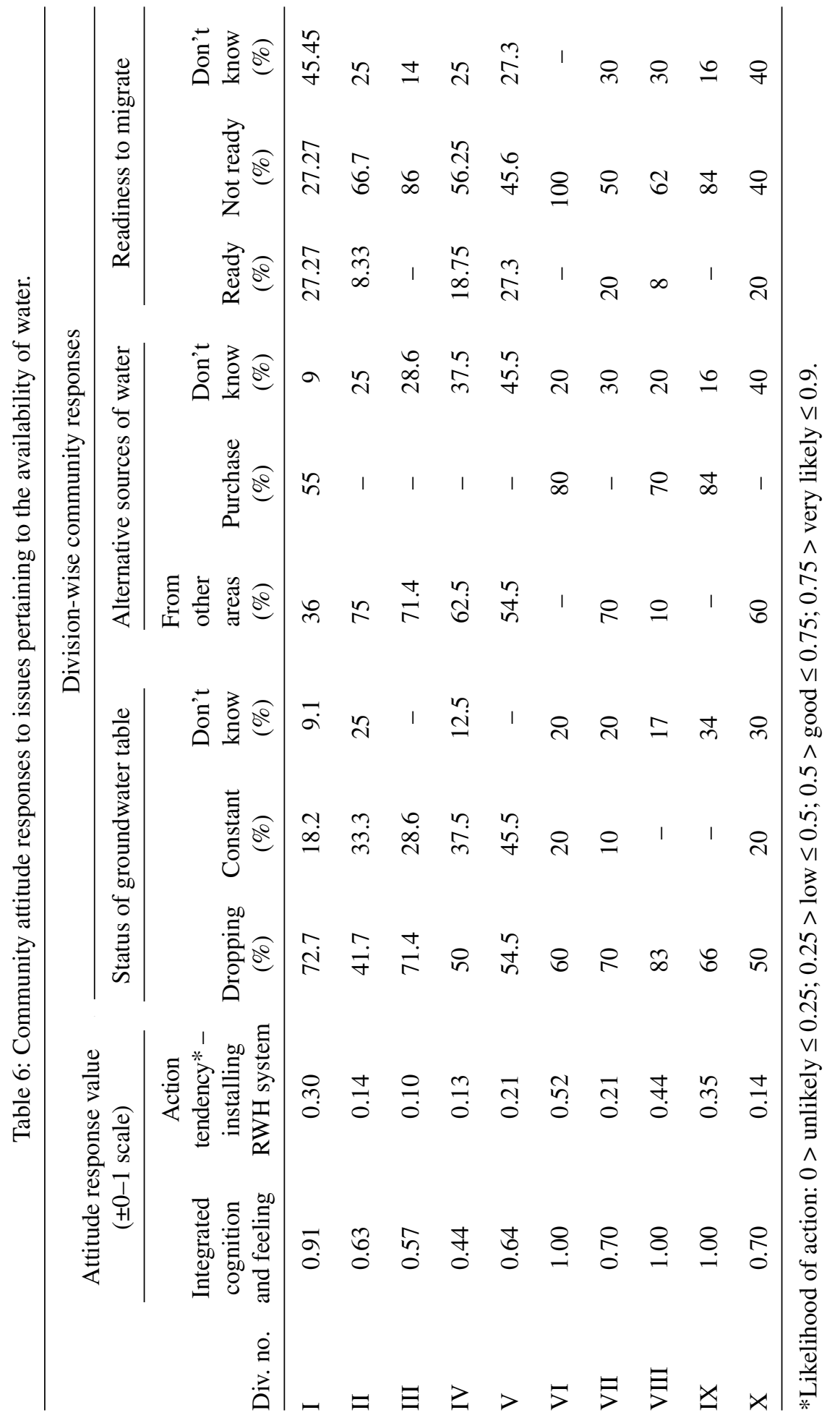


Table 7: Likely sustainability (division-wise) trends attributed to water availability - summary.

\begin{tabular}{|c|c|c|c|c|c|}
\hline \multirow[b]{2}{*}{ Div. no. } & \multicolumn{3}{|c|}{ Installation - rain water harvesting system } & \multicolumn{2}{|c|}{$\begin{array}{c}\text { Likely sustainability trends } \\
\text { (severe water scarcity scenario) }\end{array}$} \\
\hline & $\begin{array}{l}\text { Likelihood of } \\
\text { installation }\end{array}$ & $\begin{array}{l}\text { Land area as } \\
\text { percentage } \\
\text { of total area }\end{array}$ & $\begin{array}{c}\text { Impact on } \\
\text { groundwater } \\
\text { level }\end{array}$ & $\begin{array}{l}\text { Consequences of } \\
\text { seeking water from } \\
\text { other sources }\end{array}$ & $\begin{array}{l}\text { Willingness to } \\
\text { migrate }\end{array}$ \\
\hline I & Low & 18 & Mild & $\begin{array}{l}36 \% \text { likely to spend } \\
\text { an increasing } \\
\text { percentage of } \\
\text { day's time in } \\
\text { procuring water } \\
\text { from other areas } \\
\text { (TSU) } \\
\text { 55\% likely to spend } \\
\text { an increasing } \\
\text { percentage of } \\
\text { their income } \\
\text { toward purchasing } \\
\text { water (UL) }\end{array}$ & $27 \%(73 \%$ ROs $)$ \\
\hline II & Unlikely & 8 & Nil & $\begin{array}{l}75 \% \text { likely to spend } \\
\text { an increasing } \\
\text { percentage of } \\
\text { day's time in } \\
\text { procuring water } \\
\text { from other areas } \\
\text { (TSU) }\end{array}$ & $\begin{array}{l}10 \% \\
<(92 \% \text { ROs })\end{array}$ \\
\hline III & Unlikely & 2 & Nil & $\begin{array}{l}72 \% \text { likely to spend } \\
\text { an increasing } \\
\text { percentage of } \\
\text { day's time in } \\
\text { procuring water } \\
\text { from other areas } \\
\text { (TSU) }\end{array}$ & $\begin{array}{l}\text { None } \\
(100 \% \text { ROs })\end{array}$ \\
\hline IV & Unlikely & 16 & Nil & $\begin{array}{l}63 \% \text { likely to spend } \\
\text { an increasing } \\
\text { percentage of } \\
\text { day's time in } \\
\text { procuring water } \\
\text { from other areas } \\
\text { (TSU) }\end{array}$ & $18 \%(68 \%$ ROs $)$ \\
\hline
\end{tabular}


Table 7: Continued.

\begin{tabular}{|c|c|c|c|c|c|}
\hline \multirow[b]{2}{*}{ Div. no. } & \multicolumn{3}{|c|}{ Installation - rain water harvesting system } & \multicolumn{2}{|c|}{$\begin{array}{c}\text { Likely sustainability trends } \\
\text { (severe water scarcity scenario) }\end{array}$} \\
\hline & $\begin{array}{l}\text { Likelihood of } \\
\text { installation }\end{array}$ & $\begin{array}{l}\text { Land area as } \\
\text { percentage } \\
\text { of total area }\end{array}$ & $\begin{array}{c}\text { Impact on } \\
\text { groundwater } \\
\text { level }\end{array}$ & $\begin{array}{l}\text { Consequences of } \\
\text { seeking water from } \\
\text { other sources }\end{array}$ & $\begin{array}{l}\text { Willingness to } \\
\text { migrate }\end{array}$ \\
\hline $\mathrm{V}$ & Unlikely & 4 & Nil & $\begin{array}{l}55 \% \text { likely to spend } \\
\text { an increasing } \\
\text { percentage of } \\
\text { day's time in } \\
\text { procuring water } \\
\text { from other } \\
\text { areas (TSU) }\end{array}$ & $27 \%$ (72\% ROs) \\
\hline VI & Good & 4 & Low & $\begin{array}{l}80 \% \text { likely to spend } \\
\text { an increasing } \\
\text { percentage of } \\
\text { their income } \\
\text { toward purchasing } \\
\text { water (UL) }\end{array}$ & $\begin{array}{l}\text { None }(100 \% \\
\text { ROs) }\end{array}$ \\
\hline VII & Unlikely & 8 & Nil & $\begin{array}{l}70 \% \text { likely to spend } \\
\text { an increasing } \\
\text { percentage of } \\
\text { day's time in } \\
\text { procuring water } \\
\text { from other } \\
\text { areas (TSU) }\end{array}$ & $20 \%$ (60\% ROs) \\
\hline VIII & Low & 19 & Mild & $\begin{array}{l}10 \% \text { likely to spend } \\
\text { an increasing } \\
\text { percentage of } \\
\text { day's time in } \\
\text { procuring water } \\
\text { from other } \\
\text { areas (TSU) } \\
70 \% \text { likely to spend } \\
\text { an increasing } \\
\text { percentage of } \\
\text { their income } \\
\text { toward purchasing } \\
\text { water (UL) }\end{array}$ & $8 \%(68 \%$ ROs $)$ \\
\hline
\end{tabular}


Table 7: Continued.

\begin{tabular}{|c|c|c|c|c|c|}
\hline \multirow[b]{2}{*}{ Div. no. } & \multicolumn{3}{|c|}{ Installation - rain water harvesting system } & \multicolumn{2}{|c|}{$\begin{array}{l}\text { Likely sustainability trends } \\
\text { (severe water scarcity scenario) }\end{array}$} \\
\hline & $\begin{array}{l}\text { Likelihood of } \\
\text { installation }\end{array}$ & $\begin{array}{l}\text { Land area as } \\
\text { percentage } \\
\text { of total area }\end{array}$ & $\begin{array}{c}\text { Impact on } \\
\text { groundwater } \\
\text { level }\end{array}$ & $\begin{array}{l}\text { Consequences of } \\
\text { seeking water from } \\
\text { other sources }\end{array}$ & $\begin{array}{l}\text { Willingness to } \\
\text { migrate }\end{array}$ \\
\hline IX & Low & 12 & Mild & $\begin{array}{l}84 \% \text { likely to spend } \\
\text { an increasing } \\
\text { percentage of } \\
\text { their income } \\
\text { toward purchasing } \\
\text { water (UL) }\end{array}$ & $\begin{array}{l}\text { None }(100 \% \\
\text { ROs) }\end{array}$ \\
\hline $\mathrm{X}$ & Unlikely & 9 & Nil & $\begin{array}{l}60 \% \text { likely to spend } \\
\text { an increasing } \\
\text { percentage of } \\
\text { day's time in } \\
\text { procuring water } \\
\text { from other areas } \\
\text { (TSU) }\end{array}$ & $20 \%$ (50\% ROs) \\
\hline
\end{tabular}

ROs, resident owners; TSU, time spent unproductively; UL, uneconomical livelihood.

1. The percentage of the community indulging in unhygienic sanitation and waste disposal practices is significantly high, particularly the divisions belonging to the EWS (see Table 3). Even among affluent sections of the community, Division-IX, (40\%) are found to dispose their solid waste into the open, despite the availability of municipal solid waste collection services.

2. In Table 6 , it is possible to observe that despite the majority of the community being aware of the dropping water table, and also about RWH systems, their initiatives to actually install RWH systems is low. This can be attributed to the fact that the community expects water supply to be the responsibility of the city municipality (under political pressure), and do not consider investing in RWH as a self-pressing concern. Hence, improvement in the status of the water table is unlikely.

Policy interventions such as 'awareness programs' are likely to be ineffective in such cases, as the community is already aware but uninterested. Interventions such as 'compulsory RWH system installation', or provision of subsidies (or other incentives) toward RWH installations are more likely to be effective.

3. Table 7 provides a summary of the varying sustainability trends, attributed to water availability. A significant proportion of the EWS' (Divisions-II, III, IV, V, VII, X) are likely to spend an increasing amount of their day's productive time in procuring water. The more affluent sections of the community would tend to spend an increasing percentage of their monthly income toward procuring water. Both trends are unsustainable and impair the general well-being of the community.

Also, it is found that most resident-owners (as compared to resident-tenants) are unwilling to migrate under conditions of severe water scarcity. 


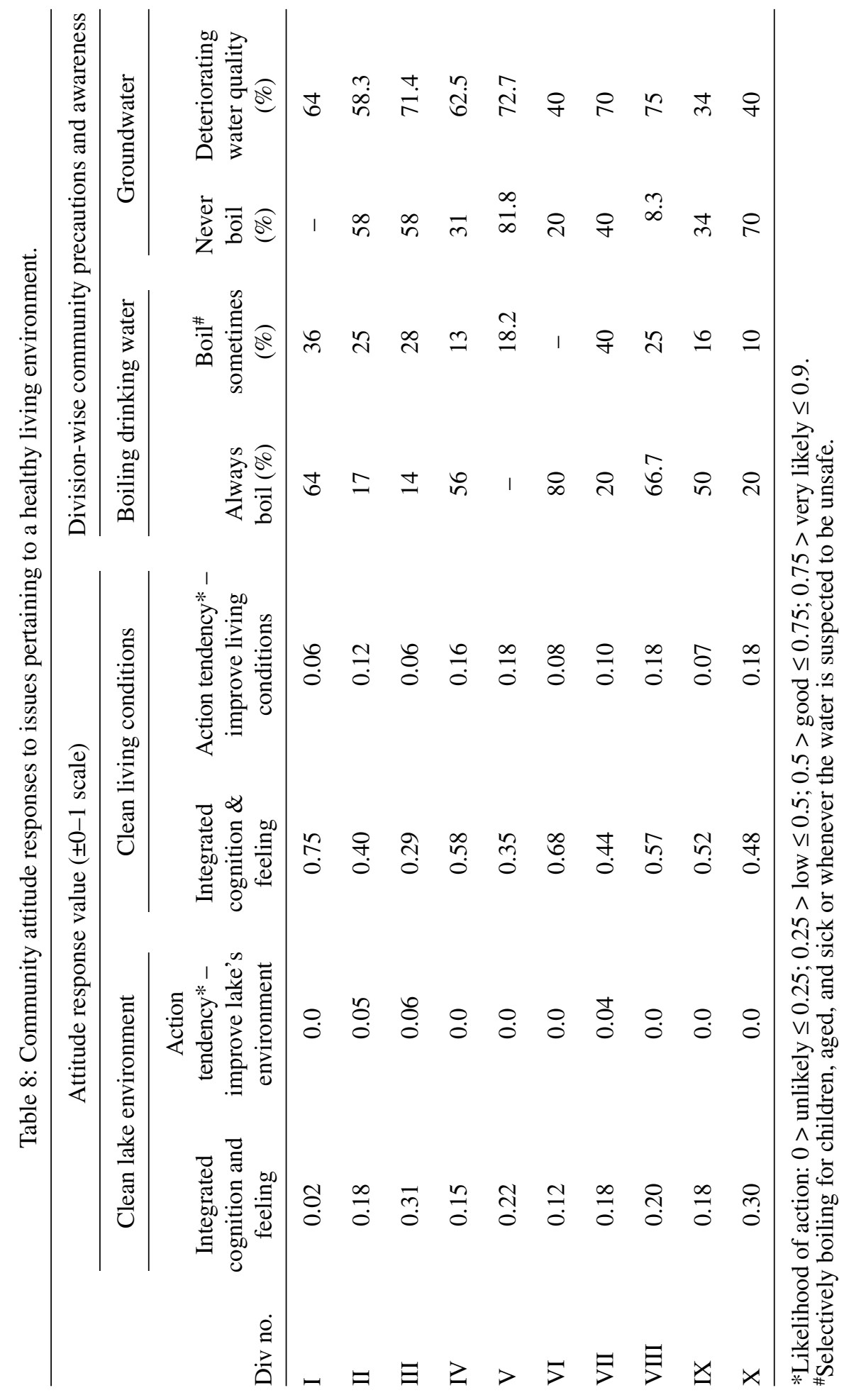


Monto Mani et al., Int. J. Sus. Dev. Plann. Vol. 2, No. 4 (2007)

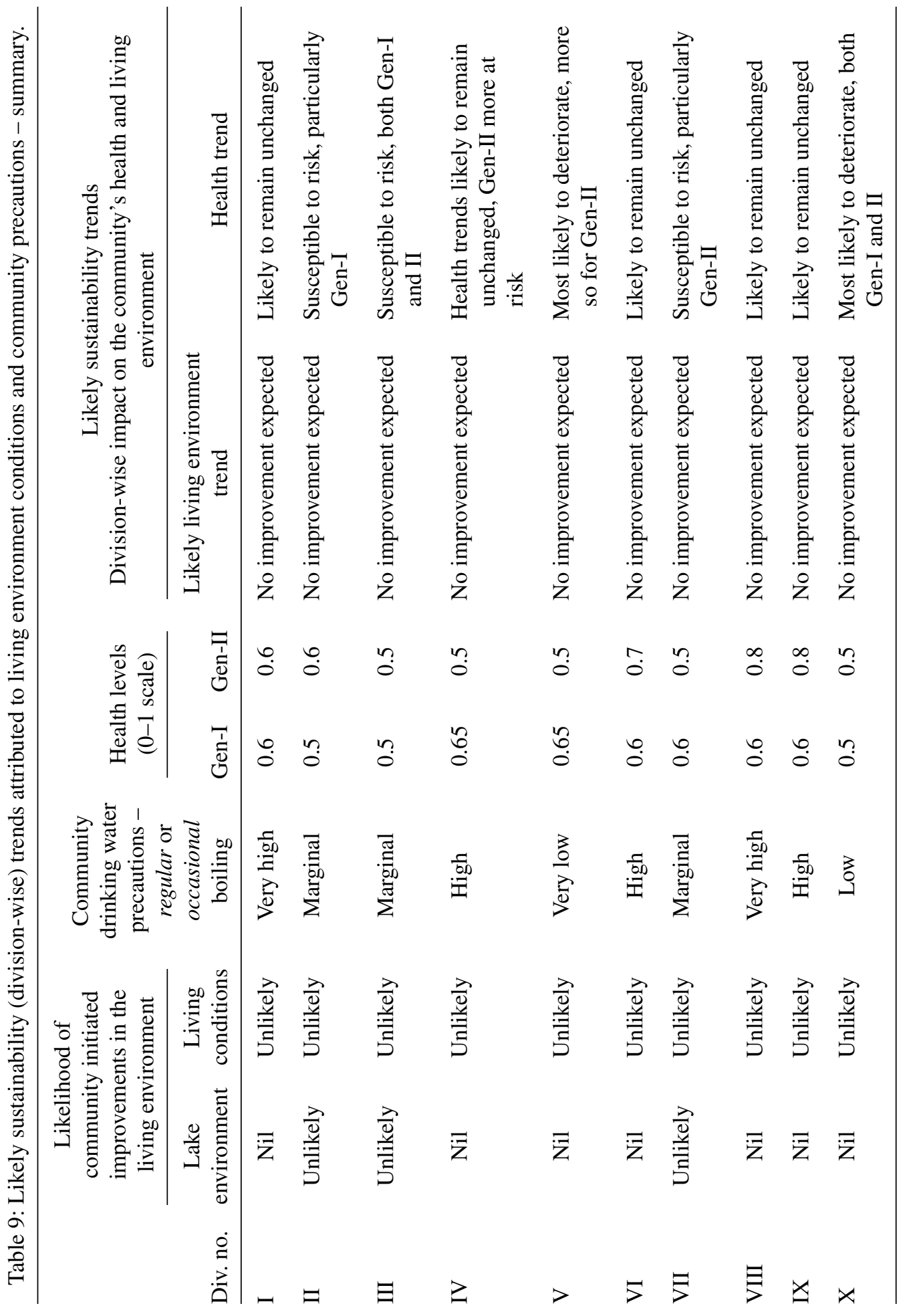


4. In Table 8 , it is possible to observe that the community's initiative (both feelings and action tendency) toward improving the lake's environmental conditions is low. In the case of improving their living conditions, the initiative to act is poor.

Also, despite the awareness within the community of the deteriorating water quality, a large proportion of the community still prefers to consume water without boiling $(81.8 \%$ for Division- $\mathrm{V}$, where $72.7 \%$ are aware that the water quality is poor). Such practices, attributed to community attitude, would result in health trends that threaten sustainability, as can be seen in Table 9 .

To summarize, given the current state of the community lifestyles, living environment and attitudes, the sustainability of the younger (future) generation (Gen-II) is more risk prone, as compared to the older (current) generations. The role of attitude in sustainable development can be clearly discerned from the current study, where most of the issues that threaten the community's sustainability can be attributed to apathetic community attitude. Policy interventions aimed at increasing community awareness are most unlikely to be effective, as the awareness levels on various issues are currently high. Interventions, such as imposing compulsory laws/resolutions or provision of incentives/subsidies are most likely to be effective for sustainable development.

\section{SUMMARY}

Human actions have serious implications in man-nature relationships that govern sustainability. The living environment comprises the natural environment and the built-environment. A human settlement's built environment evolves to accommodate and support human activities. Features of the built environment often interfere and alter natural processes necessary to support life. The activities pursued by a community are strongly determined by its prevailing attitude. Sustainability evaluation is an important exercise that can support decision-making for sustainable development. This essentially requires a systemic study into the linkages between human (attitude) activities and the living (built and natural) environment processes.

This paper presents an integrated study to evaluate the sustainability of a human settlement based on the community's attitude and state of the living environment. An urban residential settlement in South India has been chosen as the study area. Pertinent progress has been maintained through extensive consultations with a group of multi-disciplinary experts. The methodology adopted in this study, results, and the salient conclusions drawn are presented in this paper.

\section{REFERENCES}

[1] Churchill, C.J. \& Baetz, B.W., Development of decision support system for sustainable community design. Journal of Urban Planning and Development, 125(1), pp. 17-35, 1999.

[2] Choguill, C.L., Toward sustainability of human settlements. Habitat International, 20(3), pp. 5-8, 1996.

[3] UN, Report of the World Summit on Sustainable Development, United Nations publication: New York, 2002.

[4] Capello, P. \& Nijkamp, P., In search of sustainable human settlements. Ecological Economics, 40(2), pp. 151-155, 2002.

[5] Harpham, T. \& Werna, E., Sustainable urban health in developing countries. Habitat International, 20(3), pp. 421-429, 1996.

[6] Krech, D., Crutchfield, R.S. \& Ballachey, E.L., Individual in Society: A Textbook of Social Psychology, McGraw-Hill Book Company: New York, 1962. 
[7] Veitch, R. \& Arkkelin, D., Environmental Psychology: An Interdisciplinary Perspective, Prentice-Hall Inc: New Jersey, 1995.

[8] Euston, A., Community Sustainability: Agendas for Choice-making and Action, U.S. Department of Housing and Urban Development: Washington DC, 1995.

[9] Andreasen, J., Urban tenants and community involvement. Habitat International, 20(3), pp. 359-365, 1996.

[10] Ergüden, S., Cities for All. Research and Development Division (July 2000), available at www.unhabitat.org/HD/hdv4n4/intro.htm, UNCHS (HABITAT): Nairobi, 1999.

[11] Camagnia, R., Capello, R. \& Nijkamp, P., Towards sustainable city policy: an economyenvironment technology nexus. Ecological Economics, 24(1), pp. 103-118, 1998.

[12] Ortega-Villasenor, D., Taller Chapala: an integrated academic approach to sustainable development. Aquatic Ecosystem Health and Management, 2(2), pp. 105-113, 1999.

[13] Kane, J., A primer for a new cross-impact language - KSIM. Technological Forecasting and Social Change, 4(2), pp. 129-142, 1972.

[14] Richmond, B., Systems Thinking: Four Key Questions (January 2006), available at www.aertia. com/docs/isee/Systems\%20Thinking_Four\%20Key\%20Questions.pdf, High Performance Systems Inc.: Lyme, 1991.

[15] Gong, J. \& Otsubo, K., A new approach to modeling land-use change applicable to a limited data set, NIES Workshop on Information Bases and Modeling for Land Use and Cover Change Studies in East Asia, eds K. Otsubo, K. Tsuboi \& M. Hiromoto, NIES-CGER Publication: Tsukuba, pp. 27-34, 1999.

[16] Hinrichsen, D., Robey, B., \& Upadhyay, U.D., Population Reports: Solutions for a Water-Short World, School of Hygiene and Public Health, Johns Hopkins University: Baltimore, 1999.

[17] Swain, A., Water wars: fact of fiction? Futures, 33, pp. 769-781, 2001.

[18] TN-PWD, Report on Environmental Improvement of the Waterways in Madras City, Public Works Department, Government of Tamilnadu: Chennai, 1988.

[19] ICMAM-PD, Environment Management Capacity Building: Coastal Profile for ICMAM Plan Area of Chennai, Integrated Coastal and Marine Area Management (ICMAM) Project Directorate: Chennai, 2000.

[20] Marsh, P., Life Style: Your Surroundings and How They Affect You, Sidgwick \& Jackson: London, 1990.

[21] WHO, Our Planet, Our Health, WHO Commission on Health and Environment, Oxford University Press: New Delhi, 1993.

[22] WHO, Guidelines for Drinking-Water Quality: Volume 3 - Surveillance and Control of Community Supplies, World Health Organization: Geneva, 1997.

[23] Carter, R.C., Tyrrel, S.F. \& Howsam, P., Impact and sustainability of community water supply and sanitation programmes in developing countries. Journal of the Chartered Institution of Water and Environmental Management, 13, pp. 292-296, 1999.

[24] IIPS, National Family Health Survey (NFHS-2), India, 1998-99: Assam, International Institute for Population Sciences (IIPS): Mumbai, 2002.

[25] CSIRO, A New Perspective for Urban Water Systems (June 2000), available at www.dbce.csiro. au/inno-web/0698/water.htm, Commonwealth Scientific \& Industrial Research Organization (CSIRO): Dickson, 1998.

[26] Bosch, C., Hommann, K., Sadoff, C. \& Travers, L., Poverty Reduction Strategy Papers Sourcebook: Water, Sanitation and Poverty (May 2001), available at www.worldbank.org/poverty/ strategies/index.htm, World Bank publication: Washington DC, 2000. 
[27] WHO/UNICEF, Global Water Supply and Sanitation Assessment 2000: Water Supply and Sanitation Sector Questionnaire - 1999, WHO and UNICEF Publication: Geneva, 2000.

[28] Burrill, A., Assessing the Societal Value of Water in its Uses, Institute for Prospective Technological Studies: Spain, 1997. 